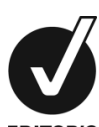

EDITOR'S

CHOICE

${ }^{1}$ Department of

Periodontology, Faculty of Dental Sciences, King George's Medical University, Lucknow, Uttar Pradesh, India ${ }^{2}$ Department of Pathology, King George's Medical University, Lucknow, Uttar Pradesh, India

\section{Correspondence to} Dr Shilpa Trivedi, shilpa.knp@gmail.com

Accepted 4 February 2016

\title{
Extramedullary plasmacytoma of the gingiva
}

\author{
Shilpa Trivedi, ${ }^{1}$ Jaya Dixit, ${ }^{1}$ Madhu Mati Goel ${ }^{2}$
}

\section{DESCRIPTION}

Extraosseous plasmacytoma, also referred to as extramedullary plasmacytoma (EMP), is defined by ICD-10 as a localised plasma cell neoplasm that arises in tissues other than bone. ${ }^{1}$ It is considered one of the three variants of plasma cell neoplasms, the other two being multiple myeloma (MM) and solitary bone plasmacytoma (SBP) (also known as medullary plasmacytoma).

EMP is a relatively rare lesion, constituting 3\% of all plasma cell neoplasms. ${ }^{2}$ About $1 \%$ of head and neck tumours are EMPs. It is found most commonly in the head and neck region, with $80 \%$ of cases occurring in the nasopharynx, paranasal sinuses and tonsils. ${ }^{3}$ EMPs occur less commonly in the gingiva. The first case was documented by Martinelli and Rulli ${ }^{4}$ in 1968 as a sessile neoplasm in the gingiva from the lower left to right canine, which could be confused with chronic gingivitis. Peison et $\mathrm{al}^{5}$ reported another case extending from the maxillary right to left canine which was a polypoid growth. The present case report discusses a rarely described extramedullary plasmacytoma of the gingiva.

A 45-year-old female patient reported to the Periodontology Department with the chief complaint of swelling of the gingiva in the upper anterior region. The patient complained of difficulty in practicing oral hygiene and a poor aesthetic appearance. The gingival mass was painless, not associated with bleeding and of 6 months' duration. The patient's medical history was non-contributory.

On intra-oral examination, the gingival mass was oval in shape, with a lobulated appearance and measured $3 \times 1.5 \mathrm{~cm}$. The lesion was reddish, sessile, firm and non-tender, involved the labial gingiva and alveolar mucosa, and extended from the distal surface of the right upper canine to the mesial surface of the left upper central incisor. The surface was smooth with no ulceration or pus discharge (figure 1). There was no associated tooth mobility. A panoramic radiograph and intra-oral

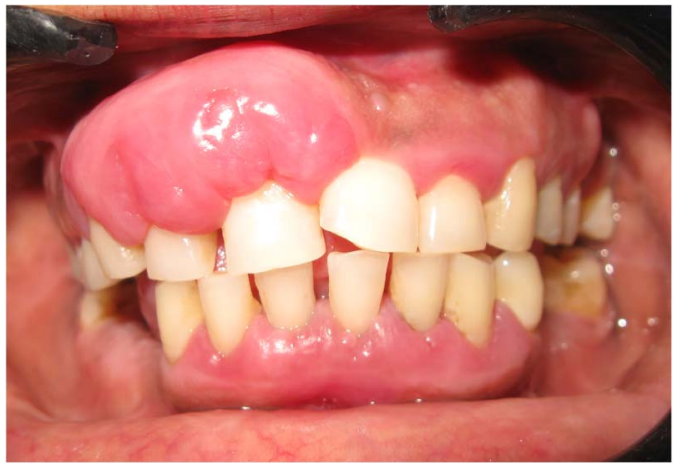

Figure 1 Clinical presentation of the case.

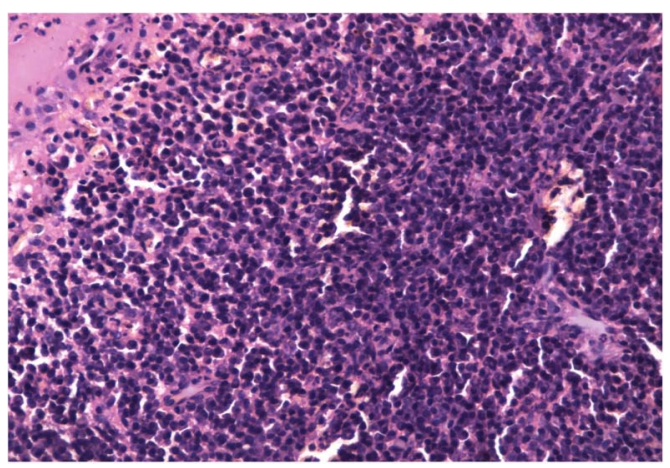

Figure 2 Microphotograph at $\times 20$ magnification with H\&E staining.

periapical radiographs did not show bone loss. Routine blood investigations were within normal limits. A differential diagnosis of chronic inflammatory enlargement, pyogenic granuloma and peripheral giant cell granuloma was considered.

An incisional biopsy was performed and the tissue was sent for histopathological examination. The section showed epidermis lined with stratified squamous epithelia. The subepithelial stroma showed diffuse sheets of plasma cells. The plasma cells were mainly mature and variable in size, with an eccentric nucleus and perinuclear halo surrounded by abundant eosinophilic cytoplasm. Quite a few binucleate and multinucleate plasma cells were also seen (figures 2 and 3 ). Immunohistochemistry for CD 138 showed diffuse membranous and cytoplasmic positivity (figure 4). Immunohistochemistry for cytokeratin, synaptophysin and CD 20 was negative.

The laboratory investigations did not show any signs of anaemia, hypercalcaemia or renal failure. Serum protein electrophoresis demonstrated normal levels of IgG and IgA, and Bence-Jones protein was not detected in the urine. A skeletal survey did not show any abnormalities. Thus, MM

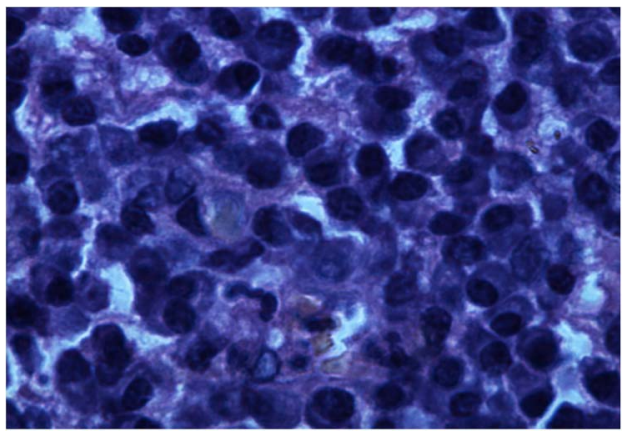

Figure 3 Microphotograph at $\times 100$ magnification with $\mathrm{H} \& \mathrm{E}$ staining showing binucleated and multinucleated plasma cells. 


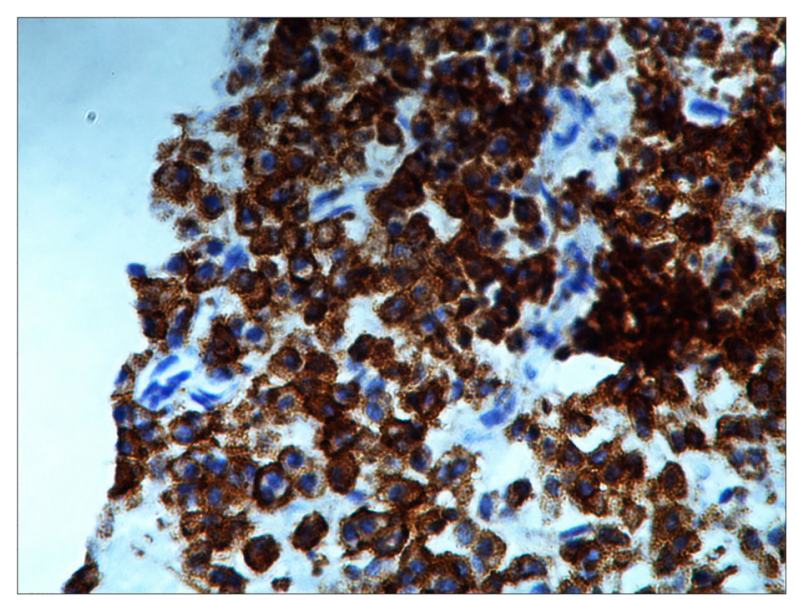

Figure 4 Immunohistochemistry for CD 138 showing diffuse membranous and cytoplasmic positivity.

was ruled out and on the basis of clinicohistopathological examination, a confirmatory diagnosis of plasmacytoma was made.

The patient was managed by radiotherapy to the affected area (40 Gray over 4 weeks) and has been asymptomatic for 1 year. Radiotherapy is the preferred treatment option as EMPs are highly radiosensitive tumours, with $80-100 \%$ of patients achieving local control. ${ }^{6}$ Dimopoulos $e t a l^{2}$ reported that patients with a solitary extramedullary plasmacytoma have a better prognosis than patients with SBP or MM because after 10 years almost $70 \%$ of patients with EMP remain disease-free. It has also been suggested that plasmacytomas arising from the soft tissues of the nasopharynx, oral cavity or larynx, and not extending into adjacent bone, have a better prognosis compared to those having significant bony involvement, such as those in the maxilla, mandible or alveolus.

However, it is noteworthy that almost $40 \%$ of patients ultimately develop $\mathrm{MM}$, so there is considerable associated risk. ${ }^{7}$ Hence, close follow-up is strongly recommended even after treatment for plasmacytoma.

As EMP affecting the gingiva is very rare, the differential diagnosis in the present case did not include plasmacytoma.

\section{Learning points}

- Extramedullary plasmacytoma is a localised plasma cell neoplasm, and is one of three plasma cell neoplasm variants, the other two being multiple myeloma (MM) and solitary bone plasmacytoma.

- Extramedullary plasmacytoma, although rare, may occur in the gingiva.

- Almost $40 \%$ of patients ultimately develop MM, so there is considerable associated risk, and the correct diagnosis and differentiation from other types of gingival enlargement is of the utmost importance.

Contributors ST: management of the case, article search and manuscript preparation. JD: supervision of case management, editing and final approval of the manuscript. MMG: histopathological guidance, editing and final approval of the manuscript.

Competing interests None declared.

Patient consent Obtained.

Provenance and peer review Not commissioned; externally peer reviewed.

\section{REFERENCES}

1 Swerdlow SH, Campo E, Harris NL, et al. WHO classification of tumors of haematopoietic and lymphoid tissues. 4th edn. Lyon, France: International Agency for Research on Cancer (IARC), 2008.

2 Dimopoulos MA, Kiamouris C, Moulopoulos LA. Solitary plasmacytoma of bone and extramedullary plasmacytoma. Hematol Oncol Clin North Am 1999;13:1249-57.

3 Regezi JA, Sciubba J, Jordan RCK. Oral pathology: clinical pathologic correlations. 4th edn. Philadelphia: W. B. Saunders, 2003.

4 Martinelli C, Rulli MA. Primary plasmacytoma of the soft tissue (gingiva): report of a case. Oral Surg Oral Med Oral Pathol 1968;25:607-9.

5 Peison B, Benisch B, Coopersmith EG. Primary plasmacytoma of the gingiva. J Oral Maxillofac Surg 1982;40:588-9.

6 Hughes M, Soutar R, Lucraft $H$, et al. Guidelines on the diagnosis and management of solitary plasmacytoma of bone, extramedullary plasmacytoma and multiple solitary plasmacytomas: 2009 update. http://www.bcshguidelines.com/documents/solitary_ plamacytoma bcsh FINAL 190109.pdf (accessed 1 Feb 2016).

7 Webb CJ, Makura ZG, Jackson SR, et al. Primary extramedullaryplasmacytoma of the tongue base. Case report and review of the literature. ORL J Otorhinolaryngol Relat Spec 2002;64:278-80.

Copyright 2016 BMJ Publishing Group. All rights reserved. For permission to reuse any of this content visit

http://group.bmj.com/group/rights-licensing/permissions.

BMJ Case Report Fellows may re-use this article for personal use and teaching without any further permission.

Become a Fellow of BMJ Case Reports today and you can:

- Submit as many cases as you like

- Enjoy fast sympathetic peer review and rapid publication of accepted articles

- Access all the published articles

- Re-use any of the published material for personal use and teaching without further permission

For information on Institutional Fellowships contact consortiasales@bmjgroup.com

Visit casereports.bmj.com for more articles like this and to become a Fellow 